H A R VAR D

\title{
The insurance industry in Brazil: a long-term view
}

Marcelo de Paiva Abreu Felipe Tâmega Fernandes

\section{Working Paper}

10-109 


\title{
The insurance industry in Brazil: a long-term view ${ }^{1}$
}

\author{
Marcelo de Paiva Abreu ${ }^{2}$ \\ Pontifical Catholic University of Rio de Janeiro \\ Felipe Tâmega Fernandes ${ }^{3}$ \\ Harvard Business School
}

\begin{abstract}
This paper surveys the formation and development of insurance business in Brazil. It describes its origins, from the colonial times and imperial era to recent events. Particular attention is given to regulatory changes, showing how they evolved in response to macroeconomic shocks that affected the Brazilian economy during this period.
\end{abstract}

JEL Classification Code: G22, G38, L50, N46.

Keywords: Insurance, Brazil, Regulation.

June 2010

${ }^{1}$ Paper prepared for Swiss Re 150th anniversary publication. The authors thank comments from Niels Viggo Haueter (Swiss-Re), Geoffrey Jones, Henrique Oliveira (Swiss-Re), and Mira Wilkins. The usual disclaimer applies.

${ }^{2}$ Professor of Economics, Department of Economics, PUC-Rio. Pontifícia Universidade Católica do Rio de Janeiro, Rua Marquês de São Vicente, 225 - Gávea 22451-900 Rio de Janeiro, RJ. Tel: +55 21 3527-1078, email: mpabreu@econ.puc-rio.br.

3 Newcomen Fellow, Harvard Business School, Soldiers Field, Baker Library | Bloomberg Center 173, Boston, MA 02163, USA. Telephone: +1 617495 6224, email: ffernandes@hbs.edu. 


\section{The insurance industry in Brazil: a long-term view}

Brazilian economic history from the 1860s was dominated by balance of payments shocks and spiraling inflation. Wide fluctuations in commodity prices, in the supply of foreign capital and also in the ability to attract foreign capital led to recurrent fiscal shocks, high inflation and foreign exchange depreciation. In spite of a better growth performance between 1900 and 1980 than in the first eighty years of independence (1822-1900), volatility of the exchange rate and domestic inflation increased significantly. After 1980, growth performance deteriorated sharply, with GDP per capita growing under $0.5 \%$ yearly for a quarter of a century. A unit of domestic currency at the

time of independence in 1822 was equivalent to $2.75^{*} 10^{15}$ units of domestic currency in 1994 when yearly inflation was finally brought under control.

There was always room for public policies that tended to have significant distributive impact favoring selected groups of the population. An important example was coffee "valorisation" policies adopted early in the $20^{\text {th }}$ century with the intention of enhancing world prices through stockpiling. But other such policies became the rule after the 19281932 great depression: high protection, quantitative import measures and foreign exchange controls, as well as discriminatory regulatory legislation that significantly affected the volume and distribution of foreign investment. Much of this chapter is on such fluctuations and their impact on the attractiveness of the Brazilian market for foreign capital, direct and otherwise, with emphasis on insurance and reinsurance companies, among other financial institutions. The focus on economic influences is due to the absence of major natural catastrophes that could have otherwise caused significant impacts on the insurance market.

\section{Early development: $1808-1900$}

The history of insurance companies in Brazil starts in 1808 when two insurance companies were founded in the province of Bahia: Companhia de Seguros Boa Fé and Companhia de Seguros Conceito Público. However, the development of this business 
would be very slow, due to the lack of economic opportunities and political instability. The institutional framework was very lax and not adapted to the specificities of the country as early legislation on insurance was borrowed from Portugal.

In 1822, Brazil became independent from Portugal and the Brazilian Empire was established by the son of the Portuguese king. After a period of political instability and regional rebellions his son succeeded to the throne in 1841 and was to remain 48 years in power, a period during which Brazil would experience significant social and economic transformations.

Before the 1850s, there was very little development of the insurance business in Brazil. Information on insurance firms for this period is at best patchy. From 1822 to 1860, eighteen companies were granted authorisation to open businesses in Brazil ${ }^{4}$ but it is not known if they were ever organized or how long they lasted. From their names they all seemed to have had Brazilian (or Portuguese) capital. ${ }^{5}$ These companies operated mostly in maritime insurance (8 out of 18), but there were other insurance branches being developed early on, such as: life insurance (1 company), slave insurance (2 companies), mutual insurance (1 company) and fire insurance (3 companies) ${ }^{6}$. The country was politically unstable and commercial activities did not seem very promising. However, by the 1850s, prospects had changed. In 1845, the last secessionist revolt had been controlled and, thanks to protectionist legislation, incipient factories started to emerge which were further fostered by funds released by the end of the transatlantic slave trade in 1850. The country was also experiencing an economic boom as coffee exports expanded. The development of railways increased the economic potential of the coffee

\footnotetext{
${ }^{4}$ Brasil (1947). However, Saes and Gambi (2009, Graph 1, p. 3) found that 17 insurance companies were granted authorization to open business in Brazil from 1822 to 1850.

${ }^{5}$ Foreign companies were not unofficially regulated until the 1860s and officially until the 1890s/1900s. There is no evidence that foreign companies operated in Brazil before the 1860s though, but as a result of poor regulation, if foreign insurance companies ever operated in Brazil before that date, it is possible that we may just not find information on their businesses from official documents in Brazil. See further below in text for details on how regulation on insurance developed in Brazil.

${ }^{6}$ From the remaining companies, it was not possible to know in exactly which branches of insurance they operated. See Brasil (1947).
} 
region by linking them with the ports of Santos and Rio de Janeiro, and thence to the consuming markets.

Amidst this positive economic and political outlook, the first commercial code was issued establishing, for the first time, specific regulations on maritime insurance. ${ }^{7}$ The new legislation defined maritime insurance ${ }^{8}$, terms of the contract ${ }^{9}$, evaluation of insured assets $^{10}$ as well as reinsurance. ${ }^{11}$ Even though the commercial code did not explicitly regulate other forms of insurance, its rules were used in the development of fire and life insurance businesses as well. Moreover, the commercial code was also important for defining the operation of joint-stock companies in Brazil that henceforth had to be registered in trade courts. The definition of rights and guarantees for stockholders allowed the expansion of joint-stock companies in general and of insurance companies in particular.

Ten years later, the first steps towards supervision were taken through new legislation. ${ }^{12}$ Banks and joint-stock companies were to submit their accounts to regulatory authorities. A deadline for all existing joint-stock companies to obtain a charter from the government was defined. Rules on the creation and organisation of joint-stock companies were detailed. However, this regulatory framework is likely to have had little impact on insurance companies businesses. It targeted mostly banks as it was a response to the 1857 banking crisis and thus ought to be analyzed in the context of the ensuing wave of orthodox monetarism in the 1860s.

\footnotetext{
${ }^{7}$ Law 556 of June 25, 1850. Código Commercial 1850, Titles VIII to XIII (Second Part 'On Maritime Commerce').

${ }^{8}$ Código Commercial 1850, Title VIII, chapter I.

${ }^{9}$ Código Commercial 1850, Title VIII, chapter II.

${ }^{10}$ Código Commercial 1850, Title VIII, chapter III.

${ }^{11}$ Código Commercial 1850, Title VIII, chapter II, article 687.

12 Decretos 2679, 2686 and 2711. See Brasil. Ministério da Fazenda. Ministro José Maria da Silva Paranhos, Proposta e Relatório do Anno de 1860 Apresentados à Assembléia Geral Legislativa na $1^{\text {a }}$ Sessão da $11^{\text {a }}$ Legislatura (inclui Annexos) 1861.
} 
During the Empire, the banking sector suffered successive crises generally associated with periods of illiquidity. These periods of illiquidity were, in turn, a consequence of the centralized nature of the banking sector at the capital, Rio de Janeiro, and the seasonality involved in the production of commodities such as coffee. Together, these two factors meant that at specific periods of the year, money was drained from the capital to the interior to meet the planters' financial obligations.

Such was the case in 1864, when the banking sector was severely hit. On top of inherent problems and inadequacies of the financial system, private banks lent money to the agricultural sector against dubious collateral, while maintaining large current accounts that could be drawn at any moment. These unstable portfolios bypassed the legal restrictions imposed in 1860 on corporations. ${ }^{13}$ The government responded by imposing new regulations on these private banks and also on the insurance business by extending supervision over mutual insurance companies, which had been hitherto unregulated. ${ }^{14}$

This regulatory framework was thus constantly evolving. As can be seen, regulatory changes usually occurred as a response to crises, especially in the banking sector. Indeed, the insurance sector was initially regarded as an appendix of the banking system and little specific attention was paid to it. Until 1872, there was no mention to the functioning or operation of insurance companies in the annual reports of the Ministry of Finance (Ministério da Fazenda). In 1871-72, for the first time, the report mentioned income generated from taxation on industries and professions broken down by sectors, discriminating the insurance sector separately. It was the first time the insurance sector deserved a separate focus. According to the data provided, six Brazilian insurance companies paid about US\$255,000. ${ }^{15}$ No mention was made to foreign insurance companies in Brazil, which remained pretty much unregulated (or at best unnoticed) until

\footnotetext{
${ }^{13}$ Villela (1999).

${ }^{14}$ Decree 3189. See Instituto de Resseguros do Brasil (1942), 31-32.

15 Brasil. Ministério da Fazenda. Ministro José Maria da Silva Paranhos, Proposta e Relatório do Anno de 1872 Apresentados à Assembléia Geral Legislativa na 2a Sessão da $15^{\mathrm{a}}$ Legislatura (inclui Annexo) 1873. For exchange rates see www. ipeadata.gov.br.
} 
1895, despite the fact that British, American, Portuguese, German and Spanish companies had been operating in Brazil since the 1860s.

Overall, from 1850 to 1889, 55 life, fire and/or maritime insurance companies were organized in Brazil ${ }^{16}$. For fifteen companies it was not possible to identify which sector of the insurance business they were operating. However, it was possible to infer that the majority of firms (twenty-two) operated in maritime insurance. It is also interesting to note a peculiarity of the Brazilian insurance system during this period. Given the importance of slavery in Brazil during the Empire, some companies were operating in slave insurance. ${ }^{17}$ Slaves sometimes comprised the majority of capital invested in agricultural undertakings, and given their risk of death or illness, it made sense for slave masters to insure their wealth. ${ }^{18}$ Therefore, slave insurance was probably a mixture of life insurance and property insurance which ceased to exist in 1888, following the end of slavery in Brazil.

In 1895, changes in regulation for insurance companies would be, once again, a response to an economic crisis. In 1889, a peaceful revolution replaced the Empire by a Republican regime. The inadequacies of the banking system were deepened by the end of slavery in 1888 and a huge inflow of immigrants for coffee plantations. By creating a mass of salaried workers in the hinterland, the periodic scarcity of financial means became more acute. To face these difficulties the authorities sought to increase the capacity of the system to create money. Amidst the difficulties raised by the political transition to a republican regime, the money supply increased faster than planned, fuelling a stock mania in the Rio de Janeiro Stock Exchange. Fictitious companies were

${ }^{16}$ This figure excludes branches of foreign companies as well. See Brasil (1947).

17 Companhia de Seguros contra a Mortalidade de Escravos - Previdência (later Companhia Mútua de Seguros de Vida de Escravos), Companhia de Seguros de Vida de Escravos, Companhia Util-Previdência de Seguros contra a Mortalidade de Escravos, Companhia de Seguro de Vida de Escravos União Fluminense, Companhia de Seguros Marítimos, contra o Fogo e de Vida de Escravos Perseverança and Companhia de Seguros sobre a Vida de Escravos - União.

${ }^{18}$ Unfortunately, it was not possible to locate the archives of companies operating in slave insurance but newspapers may contain some clues of their operation. 
created whose stocks eventually ended up in the issuing banks' balances, making it very difficult to clean up the financial system. The Baring Brothers crash in Argentina and the consequent crisis in London made things worse as the influx of foreign capital stalled. The external crisis would in the end drive the country to a renegotiation of the Brazilian foreign debt in 1898 and a funding loan. ${ }^{19}$

Insurance companies did not seem to have been a direct target of this share mania: only 16 insurance companies were organized from 1890 to 1897. However, the financial crisis fostered new changes in the regulatory framework. In the wake of the crisis, the government tightened the regulation on foreign insurance companies. Decree 294, of 1895, stipulated that foreign life insurance companies had to invest all their reserves in national assets (real estate, mortgages, shares of railroads, banks or industrial companies or long-term deposits in banks operating in Brazil). Moreover, charters would be granted only after the deposit of 200 contos de réis (US\$40,500 at the 1895 exchange rate) at the National Treasury and these companies had to maintain their headquarters in Rio de Janeiro where they would be subject to supervision 'whenever suited the Ministry of Finance'. ${ }^{20}$ This tighter regulation aroused the objection of foreign insurance companies towards the government making the New York Insurance Co., for instance, to close operations in Brazil. ${ }^{21}$ Even though it may be argued that the regulation was sparked by nationalistic feelings, its underlying motivation was the balance of payments crisis. These companies were accused of remitting all their reserves and profits to their headquarters abroad, deepening the external account gap. Indeed, the poor data available back the government's claim. An analysis of foreign companies operating in Bahia in 1874 shows that the 'Imperial Fire Insurance’, 'Liverpool \& London Globe Insurance Co.' (both from Britain) and 'Garantia' (from Portugal) remitted the totality of their insurance premiums

\footnotetext{
${ }^{19}$ Franco (1989), pp. 11-30.

${ }^{20}$ Instituto de Resseguros do Brasil (1942), pp. 35-43.

${ }^{21}$ Póvoas (2000), pp. 165-166. Actually, the company did not leave Brazil. It only ceased to contract new insurance policies as the company had to manage its portfolio until the last policy expired. As shown later here, the company in the end resumed operations.
} 
and profits to their headquarters. In contrast, the 'Royal Insurance Company' of Liverpool deposited all their funds in the 'New London and Brazilian Bank Ltd.'. ${ }^{22}$

Overall this new legislation achieved mixed results. On the one hand, it stipulated a reserve fund of 200 contos to protect insureds and created a supervisory role for the Ministry of Finance. On the other hand, the reserve fund was the same regardless of the size of operations, thereby generating a higher burden on smaller insurance businesses. Moreover, foreign life insurance companies had henceforth to invest the totality of their reserves in an extremely underdeveloped market which was about to suffer its biggest financial crisis yet. This stipulation created a contagion channel from the stock market to the balance sheets of insurance companies. Therefore, even though insurance companies were not targeted by stock market speculation, they suffered from the crisis. As soon as the financial crisis hit, it became clear that a new regulatory framework was needed.

\section{Murtinho and beyond: 1901-1939}

Joaquim Murtinho was an extremely influential Minister of Finance in 1898-1902 who successfully implemented a stabilisation programme that reversed the sharp devaluation of the exchange rate and recovered Brazilian credit abroad after successfully servicing the the first Brazilian Funding Loan and meeting its quite stiff fiscal conditionalities. He was also responsible for the first comprehensive piece of legislation regulating the activities of insurance companies in Brazil. ${ }^{23}$

The main object of the new legislation was the creation of the General Superintendence of Insurance Companies (Superintendência Geral de Seguros). Under the auspices of the Ministry of Finance, the Superintendence was further divided into two branches: Superintendence of Maritime and Non-Maritime Insurance (Superintendência de Seguros Marítimos e Terrestres) and Superintendence of Life Insurance (Superintendência de

${ }^{22}$ Brasil. Bahia. Falla com que o Exmo. Sr. Commendador Antonio Candido da Cruz Machado abriu a $1^{\text {a }}$ Sessão da Vigésima Legislatura da Assembléia Legislativa Provincial da Bahia no dia $1^{\circ}$ de Março de 1874, Salvador, pp. 214-222.

${ }^{23}$ Decree 4270 of 10 December 1901. 
Seguros de Vida). These two branches evinced the formal separation instituted by the legislation: no company could henceforth operate in both branches of insurance business.

The Superintendences were located in the Federal Capital, Rio de Janeiro, and were responsible for supervising insurance companies operating in the Brazilian market and for advising the Ministry on issuance of charters (cartas-patente). All insurance companies had to apply for a charter to be able to operate in Brazil. This new bureaucracy would be funded by a contribution paid by the insurance companies but managed by the government. Like in the 1895 legislation, companies were also asked to deposit 200 contos to guarantee some minimum compensation from possible losses due to bad risk management. In this regard, Murtinho's Framework went actually beyond the 1895 decree: it also limited the value of the insurance business as it could not be higher than $20 \%$ of the issued capital of the company. ${ }^{24}$

The new legislation was a direct response to the 1890s financial crisis. On the one hand, Murtinho's Framework tried to make the insurance market safer by creating a ceiling to the issue of policies, by instituting a supervisory body, and by ensuring that capital would not be drained to other financial markets. On the other hand, the new legislation increased the weakness of the insurance market as the domestic financial market was not yet developed enough to absorb all funds from insurance companies. Although it was not explicitly stated in Murtinho's Framework, insurance companies seemed to have been prevented from re-insurance activities, perhaps as a way of retaining their funds in Brazil too. ${ }^{25}$ This requirement made more difficult to dilute risks. Moreover, the legislation was perceived as very xenophobic by discriminating against foreign companies and by forcing them to abide by national laws.

Indeed, the issuance of Decree 4.270 was followed by a struggle between Murtinho and the foreign insurance companies. In the annual report of the Ministry of Finance for 1901,

\footnotetext{
${ }^{24}$ Instituto de Resseguros do Brasil (1942), pp. 44-84.

${ }^{25}$ Between 1895 and 1901, several companies changed their statutes to include a clause that forbade them to reinsure any assets. See Brasil. Ministério da Fazenda. Relatório, for these years.
} 
he stated that out of 18 Brazilian insurance companies registered in the Federal Capital, 15 abode by the new rules, 2 companies entered liquidation ('Atalaya' and 'Bonança'), and one refused to accept it ('Equitativa'). In the states, another 19 companies abode by the new legislation: 7 companies in Pará, 4 in Pernambuco, 3 in Maranhão, 2 in Bahia, 2 in Rio Grande do Sul and 1 in Ceará. Among foreign companies, no one accepted the new legislation and thus were all forbidden to carry out any new business in the country. These companies were not liquidated, as they were still allowed to manage their existing portfolios until the expiration of their last insurance contract, when they would then be forced to close their activities in the country. Among foreign companies, 3 filed lawsuits against the government. ${ }^{26}$

Murtinho argued that foreign companies were characterized by an "impenetrable secret about their processes, reserves and capital”. All foreign companies but one were accused of tax evasion and unlawful remittance of funds. Furthermore, Murtinho mentioned that foreign companies would not be missed: without them, there should be more businesses for existing Brazilian insurance companies and more national companies opening business. ${ }^{27}$

In fact, Murtinho's framework was not dissimilar with what was happening elsewhere in South America. According to the Post Magazine and Insurance Monitor, "throughout South America, there is a crusade against foreign capital in insurance, and the result is most detrimental to all concerned". ${ }^{28}$ However, insurance companies - with the foreign firms in the van -- successfully pressured congress. At the end Murtinho's Framework was dropped and new legislation introduced after Murtinho left the Ministry of Finance. ${ }^{29}$ Indeed, there was a consequential increase in total capital issued by Brazilian insurance

${ }^{26}$ Brasil. Ministério da Fazenda. Ministro Joaquim Murtinho. Relatório do Ano de 1901 Apresentado ao Presidente da República dos Estados Unidos do Brasil no ano de 1902. Inclui Anexo, pp. 279-304.

${ }^{27}$ Brasil. Ministério da Fazenda. Ministro Joaquim Murtinho. Relatório do Ano de 1901 Apresentado ao Presidente da República dos Estados Unidos do Brasil no ano de 1902. Inclui Anexo, pp. 279-304.

${ }^{28}$ Post Magazine and Insurance Monitor 17, January 1889, p.13.

${ }^{29}$ Decree 5072 of 12 December 1903. 
companies. From 1901 to 1902, while all foreign companies were exiting the market, Brazilian companies increased their issued capital in 4.6 thousand contos, from 13.3 thousand contos to 17.9 thousand contos. ${ }^{30}$

The new decree was a compromise between Murtinho's Framework and the stance of foreign insurance companies. Even though all existing companies would henceforth have abide by the laws of the time they were established, the government maintained a supervisory role over the companies. However, the Superintendences were replaced by an Inspectorate of Insurance (Inspetoria de Seguros). The inspectors were still paid by the insurance companies as the financial independence of the supervisory body would only be guaranteed in $1911 .^{31}$ Other features of Murtinho's framework were maintained as well: the deposit of 200 contos at the National Treasury and the ceiling for any insurance value, now at $40 \%$ of the companies' issued capital. Furthermore, the new legislation opened room for re-insurance and instituted more clearly the amount of reserves that had to be retained in Brazil: 20\% for Maritime and Non-Maritime insurance companies and $100 \%$ for Life insurance companies. The decree stated that all companies were equal under Brazilian law, removing xenophobic elements of Murtinho’s Framework.

Murtinho's successor, Leopoldo de Bulhões, made clear that the government was aware of how insurance companies were being regulated in other countries. He argued that there were two different types of insurance market organisation. The one of the Germanic type, adopted by Germany and also by Sweden, Norway, Switzerland and Austria, which was characterized by government's monopoly of insurance. He saw this model as inefficient following the rationale provided by Albert Chaufton. ${ }^{32}$ He argued in favor of the free market as adopted by all other "civilized” places: England, France, United States, Chile,

\footnotetext{
${ }^{30}$ Brasil. Ministério da Fazenda. Ministro Leopoldo Bulhões. Relatório do Ano de 1902 Apresentado ao Presidente da República dos Estados Unidos do Brasil no ano de 1903. Inclui Anexo, Quadro n. 3.

31 Decree 9287 of 30 December 1911. Instituto de Resseguros do Brasil (1942), pp. 85104 and Póvoas (2000), pp. 168-170

${ }^{32}$ Chaufton (1884).
} 
Argentina, and Mexico, stressing though that in all these markets, free market was only possible with government regulation. ${ }^{33}$

As a result of this new legislation, foreign companies resumed operations in Brazil. In 1908, the Inspectorate of Insurance sent a comprehensive questionnaire to insurance companies operating in Brazil, providing a glance of how fast the market developed in only 6 years. In 'maritime and non-maritime insurance', there were 45 companies operating, of which 34 were Brazilian and 11 foreign-owned. Brazilian companies received premiums amounting to 12.5 thousand contos (approximately US $\$ 3,850,000$ ) compared to 3.3 thousand contos (approx. US $\$ 1,015,000$ ) for foreign-owned companies, a market share of $20.1 \%$. The total issued capital of Brazilian companies reached 17.2 thousand contos (approx. US\$5,300,000) whilst foreign insurance companies had issued only 528 contos (approx. US\$160,000). There is no information regarding payment of dividends by foreign insurance companies, but Brazilian companies paid 1.4 thousand contos in dividends in 1908 (approx. US\$430,000). ${ }^{34}$

In 'Life insurance' business, there were 8 companies operating: 7 Brazilian companies and one foreign-owned (New York Life Insurance Co.). ${ }^{35}$ Altogether, these companies closed contracts amounting to 69.2 thousand contos (approx. US\$21,300,000), with 2.8 thousand contos (approx. US\$860,000) came from NY Life Insurance Co. (NYLIC). Brazilian companies retained 41.7 thousand contos (approx. US\$12,800,000) as reserves whereas NYLIC retained 1.8 thousand conto (approx. US\$550,000). The Brazilian companies premium revenue was 15 thousand contos (approx. US\$4,600,000) and paid claims amounting to 4.7 thousand contos (approx. US $\$ 1,450,000$ ) in premiums, whilst the NYLIC earned 1.9 thousand contos (approx. US\$585,000) and paid 163 contos of

${ }^{33}$ Brasil. Ministério da Fazenda. Ministro Leopoldo de Bulhões. Relatório do Ano 1902 Apresentado ao Presidente da República dos Estados Unidos do Brasil em 1903. Inclui Anexos, pp. 99-103.

${ }^{34}$ Brasil. Ministério da Fazenda. Ministro Leopoldo de Bulhões. Relatório do Ano de 1909 Apresentado ao Presidente da República dos Estados Unidos do Brasil no Ano de 1910. Inclui Anexo, pp. 318-327.

${ }^{35}$ We are excluding here companies that offered retirement benefits. 
claims (approx. £50,000). ${ }^{36}$ The market overall market share of foreign insurance companies was thus of $8.6 \%$ and their average size smaller than that of the Brazilian firms.

During the First World War, two major events had an impact on the Brazilian insurance market. First, in 1916, the government promulgated the new Civil Code with a whole chapter devoted to insurance. It encompassed all branches of insurance, namely, 'maritime and non-maritime insurance', 'life insurance' and 'mutual insurance' and represented a clear improvement over the 1850 commercial code that was restricted to maritime insurance only. ${ }^{37}$ Secondly, as a result of Brazilian entry into the war on the Allies side, the government established a permanent supervision over German insurance companies. The following companies were under strict government supervision: 'Manheimer', 'Preussische National', 'Nord Deutsch', 'Achener und Muenchener Feuer', 'Albingia' and 'Hansa Algemeine'. ${ }^{38}$ This supervision would only be abolished after the end of hostilities. ${ }^{39}$

In 1918, there were 57 companies operating in maritime and non-maritime insurance and 31 companies in life insurance business. The former group premiums totaled 42.6 thousand contos (approx. US\$11,000,000) of which 11.6 thousand contos (approx. US\$3,000,000) came from 18 foreign-owned companies and the remainder from 13 Brazilian insurance companies. In the life insurance business, there was only one foreign company operating (NYLIC) whose total premiums in 1918 of 2.1 thousand contos (approx. US\$540,000). The rest of the market was shared by 30 Brazilian life insurance companies whose total premiums amounted to 22.2 thousand contos (approx.

${ }^{36}$ Brasil. Ministério da Fazenda. Ministro Leopoldo de Bulhões. Relatório do Ano de 1909 Apresentado ao Presidente da República dos Estados Unidos do Brasil no Ano de 1910. Inclui Anexo. pp. 318-327.

${ }^{37}$ Instituto de Resseguros do Brasil (1942), pp. 105-111.

${ }^{38}$ Decree 12470 of 13 November 1917.

${ }^{39}$ Decree 13712 of 7 August 1919. Instituto de Resseguros do Brasil (1942), pp. 119-121. 
US $\$ 5,700,000)$. In total, the market share of foreign companies in premiums increased to $21.1 \%{ }^{40}$

In 1919, a major shift occurred in the Brazilian insurance market, with the advent of work accident insurance. Employers' judicial responsibility for work accidents was legally defined. ${ }^{41}$ This law culminated a persistent effort by legislators to create some sort of protection for urban workers. ${ }^{42}$ New legislation also defined the type of insurance policies to be offered by insurance companies: 'death', 'total or permanent handicap', and 'total or permanent handicap for work'. ${ }^{43}$ The decree also stipulated compensations for 'death' and 'total or permanent handicap' as equal to the sum of three years of the employees’ wages. New opportunities were created for insurance business. ${ }^{44}$

In 1920, the government issued another important piece of legislation: it finally instituted equality between foreign and domestic insurance companies under the law, abolishing the privileges granted to companies that had been founded before Murtinho's Framework. ${ }^{45}$ It also brought about a tighter control of the government over the insurance market. ${ }^{46}$

It is interesting to note that in 1922, the ministry of finance published the total issued capital of insurance companies in Brazil amounted to 50.8 thousand contos (approx. US\$6,800,000). From this figure it is possible to infer what the government called 'total market capacity of insurance', established by the limit of $40 \%$ over capital. According to this limit, the total capacity of insurance of Brazilian companies was 13.3 thousand

\footnotetext{
${ }^{40}$ Brasil. Ministério da Fazenda. Relatório Apresentado ao Vice-Presidente da República dos Estados Unidos do Brasil em exercício pelo ministro dos negócios da Fazenda, João Ribeiro de Oliveira e Souza no Anno de 1919, pp. 284-301.

${ }^{41}$ Law 3.724 of 15 January 1919.

${ }^{42}$ Before the promulgation of the law, two other projects had been presented, in 1908 and 1915, but the issue remained unregulated until 1919.

${ }^{43}$ Decree 13498 of March 1919.

${ }^{44}$ Póvoas (2000), pp. 170-176.

${ }^{45}$ Decree 14595 of 31 December 1920.

${ }^{46}$ Póvoas (2000), p. 176.
} 
contos (approx. US $\$ 1,800,000$ ) and of foreign companies 7.3 thousand contos (approx. US $\$ 1,000,000) .{ }^{47}$

In 1925, insurance companies with a premium revenue of 146.3 thousand contos (approx. US $\$ 18,100,000$ ) of which 95.7 thousand contos (approx. US $\$ 12,000,000$ ) was generated from 'maritime and non-maritime insurance' and 50.6 thousand contos (approx. US $\$ 6,300,000$ ) from life insurance. In total, there were 18 Brazilian companies operating in life insurance with 47.4 thousand contos (approx. £1,200,000) in revenues and one single foreign-owned (NYLIC) with a revenue of 3.2 thousand contos (approx. US\$400,000). In 'maritime and non-maritime insurance', there were 45 Brazilian companies with a total revenue of 65 thousand contos (approx. US\$8,000,000) and 29 foreign companies that with a revenue of 30.7 thousand contos (approx. US\$3,800,000). ${ }^{48}$ The overall market share of foreign companies remained practically stable at $23.2 \%$ if compared to the share in 1918 but for non-life insurance it reached 32\%. See Table below for a breakdown of premiums paid by insurance companies operating in Brazil by their place of registration in 1925.

${ }^{47}$ Brasil. Ministério da Fazenda. Relatório Apresentado ao Presidente da República dos Estados Unidos do Brasil pelo ministro dos negócios da Fazenda R. A. Sampaio Vidal no ano de 1923, pp. 215-217.

${ }^{48}$ Among the foreign companies thirteen were of British origin ('Alliance Assurance', 'Commercial Union', 'Guardian', 'Liverpool and London', 'London Assurance', 'London and Lancashire', 'Motor Union', 'North British', 'Northern', 'Royal Exchange', and 'Royal Insurance'), six were Germans ('Aachener und Munchener', 'Albingia', 'Hansa', 'Mannheimer', 'Nord Deutsche' and 'Preussische'), three were from the USA ('Great American', 'The Home' and 'Niagara Fire'), two from France ('Assurance Générales' and 'L’Union'), Portugal ('Adamastor' and 'Sagres') and Argentina ('El Fenix' and 'Instituto Italo-Argentino') and one from Italy ('Assicurazioni Generali'). It is important to highlight that the two Argentine companies operating in Brazil sold premiums that totaled 600 contos (approximately US\$74,000) in 1925. See Brasil. Ministerio da Fazenda. Ministro Anibal Freire da Fonseca. Relatório do Ano de 1925 Apresentado ao Presidente da República dos Estados Unidos do Brasil no Anno de 1926. 
Premiums paid by Insurance Companies operating in Brazil by Place of Registration, 1925

\begin{tabular}{|c|c|c|}
\hline \multicolumn{3}{|c|}{ Maritime Insurance } \\
\hline Brazilian Companies & N. of Companies & Premiums \\
\hline Rio de Janeiro City, Federal District & 22 & $33,167,591$ \\
\hline Pará & 3 & 956,049 \\
\hline Maranhão & 1 & 94,966 \\
\hline Pernambuco & 3 & $1,535,910$ \\
\hline Bahia & 2 & $15,781,129$ \\
\hline State of Rio de Janeiro & 1 & 71,921 \\
\hline São Paulo & 7 & $10,099,034$ \\
\hline Rio Grande do Sul & 6 & $3,271,278$ \\
\hline Foreign Companies & N. of Companies & Premiums \\
\hline Germany & 6 & $3,589,777$ \\
\hline Argentina & 2 & 600,800 \\
\hline United States & 3 & $2,816,580$ \\
\hline France & 2 & 849,681 \\
\hline Britain & 13 & $21,731,237$ \\
\hline Italy & 1 & 432,293 \\
\hline Portugal & 2 & 691,660 \\
\hline \multicolumn{3}{|c|}{ Life Insurance } \\
\hline Brazilian Companies & N. of Companies & Premiums \\
\hline Rio de Janeiro City, Federal District & 5 & $39,197,228$ \\
\hline Maranhão & 1 & 18,362 \\
\hline Pernambuco & 1 & 14,580 \\
\hline State of Rio de Janeiro & 1 & 794,815 \\
\hline São Paulo & 9 & $4,652,718$ \\
\hline Rio Grande do Sul & 1 & $2,755,337$ \\
\hline Foreign Companies & N. of Companies & Premiums \\
\hline United States & 1 & $3,155,285$ \\
\hline \multicolumn{3}{|c|}{ Total } \\
\hline & N. of Companies & Premiums \\
\hline Maritime Insurance & 74 & $95,689,906$ \\
\hline Life Insurance & 19 & $50,588,326$ \\
\hline Brazilian Companies & 63 & $112,410,918$ \\
\hline Foreign Companies & 30 & $33,867,313$ \\
\hline
\end{tabular}

Source: Brasil. Ministerio da Fazenda. Ministro Anibal Freire da Fonseca. Relatório do Ano de 1925 Apresentado ao Presidente da República dos Estados Unidos do Brasil no Anno de 1926. Quadro n. 4, Inspetoria de Seguros. 
In the first four decades of the republican regime Brazil had developed quite substantially if not spectacularly. The economy was initially dependent on coffee production and exports. For this dependence the country paid dearly as evidenced by repeated crisis in the world markets and its repercussions for the country. However, market dominance in the world coffee market also allowed the country to control prices through stockpiling at least in certain periods. Significant industrialisation did occur after the 1890s, mostly as a diversification of the portfolio of coffee planters, urbanisation increased slowly and the infrastructure was modernized. ${ }^{49}$

It is important to note that there is very little evidence that crop insurance ever developed in Brazil during this period, despite this over-reliance on coffee. Graham (1972, p. 91) says that "[t]he Royal Insurance Company emphasized that it insured coffee and even the plantations themselves, presumably against fire” but not much additional information could be found on these transactions. Coffee prices were indeed very volatile due to the characteristics of the crop and weather conditions. Insurance remained mostly confined to the coffee trade business, especially maritime insurance. ${ }^{50}$ That is why maritime insurance came to dominate the insurance business until much later. Valorization policies may have had insurance on coffee stocks held but we were unable to find such transactions $^{51}$. Even a publication like Graham (1972) only makes general statements about insurance in coffee. Mário Pinto Serva, in turn, describes in detail the cost of production of coffee in Brazil and he makes no mention to insurance. ${ }^{52}$

The great depression of 1929-1932 had lasting effects on Brazil. Recovery of the level of activity was much swifter than in the developed economies but some of the policies

\footnotetext{
${ }^{49}$ Dean (1976).

${ }^{50}$ According to Graham (1972, p.91), "the ships that carried coffee and brought in British goods were generally insured in London, frequently by Lloyd's. Shippers could also buy insurance in Rio de Janeiro from British companies such as the Marine Insurance Company, Ltd. or the Home and Colonial Marine Insurance Company, Ltd.”

${ }^{51}$ In the first valorization scheme, stocks were mostly held in New York and Antwerp and it is possible that insurance was contracted in the USA and Belgium. In the subsequent valorization schemes, stocks were held in Brazil but usually hidden from the market to prevent prices to drop.

${ }^{52}$ Departamento Nacional do Café (1934).
} 
adopted to counter the consequences of the 1929 crash remained in place for over sixty years. Foreign loans to Brazil were sharply reduced in mid-1928, following the monetary squeeze adopted by the Federal Reserve in the United States, and ceased entirely in 1930. Brazilian exports collapsed as coffee prices fell to a third of their peak in the late 1920s as world income contracted and "coffee valorisation" policies - which depended on access to foreign loans to finance accumulation of stocks - were curtailed.

After the collapse of the gold exchange standard, concern with the impact of foreign exchange devaluation on public accounts and coffee prices - since Brazil supplied two thirds of the world demand and devaluation induced sales of stocks to realize profits - led to government intervention in the foreign exchange market setting an "official" overvalued exchange rate. The need of rationing access to cheap foreign exchange led to a comprehensive foreign exchange control. Discretionary and non-transparent allocation criteria favored "essential" uses of foreign exchange and frequently led to difficulties affecting less pressing commitments such as profit remittances. Different forms of intervention in the foreign exchange markets would persist, with only short interruptions, well into the 1990s.

In the wake of the great depression there was a rise of nationalist policies favoring autarchy and an increasing role of the state both in a normative role and as a producer of goods and services. Amidst mounting nationalism, as expressed in the constitutions of 1934 and 1937, and also in specific legislation, there were proposals to nationalize foreign insurance companies and foreign banks operating in Brazil. The 1934 constitution explicitly included a provision on the nationalisation of foreign insurance companies (article 117). In 1937, after the coup d'état, the new constitution stipulated that mining concerns, mineral and water resources as well as essential industries would be progressively nationalized (article 144). Shareholders of banks and insurance companies should be Brazilian citizens and concerns already authorized to operate in the country would be given a period to adjust to changes in the legislation. 
Exceptions were granted in a piece meal basis to foreign bank and insurance companies but the nationalist wave resulted in the creation of the Instituto de Resseguros do Brasil (IRB), a state-owned institution which for more than half a century had a monopoly on reinsurance business in Brazil and full regulatory control of the insurance business.

\section{Reinsurance state monopoly, fast economic growth and accelerating inflation: 1939-1964}

The avowed objective of government intervention in the insurance market was to limit more effectively the adverse balance of payments impact of seeking reinsurance abroad. IRB (Decree Law 1186 of 3.4.39) was given the monopoly of reinsurance business in Brazil, the task of redistributing business which exceeded its retention limits to insurance companies operating and Brazil and the monopoly of the placement of reinsurance abroad. Reinsurance with IRB of risks exceeding retention limits was made compulsory and retention tables had to be approved by the Departamento Nacional de Seguros Privados e Capitalização-DNSPC. State-controlled social security institutes held $70 \%$ of IRB's capital and the residual $30 \%$ were held by the insurance companies. ${ }^{53}$ It was decided not to place IRB under DNSPC's supervision since it was a state-controlled institution.

Much new regulatory legislation was passed in the early 1940s after the creation of IRB such as those making compulsory to reinsure with IRB at least $20 \%$ of coinsurance business, establishing minimum limits for the transfer of fire coinsurance from foreign companies to Brazilian companies.

New business opportunities were created during the war and the premium-GDP ratio increased from $0.44 \%$ in 1939 to $0.77 \%$ in 1945 and remained at this level in 1950s and early 1960s. Rough estimates for the post-World War I period indicate than the premium-

${ }^{53}$ In 1946 this was changed to 50\%-50\%. 
GDP ratio was around $0.5 \%{ }^{54}$ The number of insurance firms increased by about half in the 1940s (from 105 in 1939 to 151) and then reached 193 in the early 1960s. Thus, the average size of the firm did not increase much during the war and actually decreased until the early 1960s. The number of foreign firms actually decreased from 33 in 1939 to 25 in 1945 recovering to 35 in the early 1960s. ${ }^{55}$.It was the number of Brazilian firms which more than doubled between 1939 and 1963 (from 73 to 158). The stock of foreign direct capital of insurance firms registered with the Superintendência da Moeda e do CréditoSUMOC - a predecessor of the Central Bank of Brazil ${ }^{56}$, was negligible: in the late 1940s it was perhaps US\$ 2.4 million and in 1963 still only US\$ 5 million. The net outflow related to insurance business floated from the mid-1940s to the mid-1960s around US\$ 811 million, roughly $0.7 \%$ of stagnated exports.

Premiums in 1939 were concentrated in fire insurance (28.1\% of the total), life (38\%) and work accidents (19.2\%). ${ }^{57}$ During the war there was an increase in transportation insurance to the detriment of life insurance but this was reversed in the late 1940s. As inflation accelerated life insurance lost market share. Auto-related insurance grew steadily in response to the increased stock of motor cars and after the 1960s due to new legislation making it compulsory. In 1963, more than a quarter of premiums were related to work accident insurance, followed by fire (24\%), life (13.2\%) and auto (10.2\%). ${ }^{58}$

After 1942 the economy entered a period of high growth (approaching 7\% yearly with a population growth of $3 \%$ yearly) which was to last for twenty years. Inflation accelerated

${ }^{54}$ GDP-premium ratios remained stable in spite of rapid GDP growth, population growth and urbanisation. GDP increased at the rate of 6.5\% between 1930 and 1980 while GDP per capita increased at 3.7\% yearly. Data that are not strictly comparable indicate that the share of the population in cities with population of 20,000 and more that had increased slowly in the two decades after 1920 to reach 16 percent in 1940 rose very rapidly after wards to reach 51.5 percent in 1980. See Abreu (2008a).

55 The criteria adopted to justify the classification of an insurance company as foreign were not made public.

56 The Central Bank of Brazil was created in 1964.

57 In 1938, the share of foreign insurance companies in life insurance premiums was about 14\% and in non-life insurance premiums about 48\%. See Falcão (1941), pp. 44-59.

${ }^{58}$ Data from Anuário Estatístico do Brasil, several years. 
in the final years of the war to reach $20 \%$ yearly and, after a reduction in the immediate post-war, became chronic in the 1950s accelerating continuously to reach more than $90 \%$ yearly in 1963. A structural imbalance of public accounts was at the root of this process: government finance through the printing press is not a figure of expression as persistently high inflation combined with an usury law that limited nominal interest rates to $12 \%$ a year made it impossible to finance public deficits by issuing debt. Balance of payments constraints were also significant as the structural change in GDP favouring manufacturing had no parallel in export diversification: Brazil in the first half of the 1960s was still essentially an exporter of agricultural commodities with coffee at the top of the list. The cyclical fall of coffee prices combined with accelerated growth in the second half of the 1950s led to balance of payments difficulties and negotiated rescheduling of foreign debt service payments in 1961-1962.

Government resort to compulsory saving specifically affected insurance companies. In 1953, for instance, the newly created Banco Nacional do Desenvolvimento Econômico was partially funded by transfers drawn from a share of the increase in technical reserves of social insurance institutos, saving societies (caixas econômicas) and insurance and capitalisation companies. Regulation of limits to insurance acceptances based on assets tended to be rather restrictive on foreign companies.

In spite of adverse circumstances linked with chronic and accelerating high inflation there was no contraction of the insurance business as shown by the premium-GDP ratio between the end of World War II and 1962 as the economy expanded at the rate of 7.4\% yearly.

\section{Stabilisation and economic “miracle”: 1964-early 1980s}

The combination of high inflation and sudden collapse in the level of economic activity in a context of increasing political instability in 1962-63 was an important element to explain the military coup of 1964 . The new military regime - which was to last for more than 20 years - had an ambitious program of economic reform. First and foremost there 
was an emphasis on reduction of chronic inflation which was made possible by an overhaul of public finance. Expenditures were cut, fiscal reform was introduced and, perhaps most important of all, the legal institution of a segmentation of the nominal interest rate into "monetary correction" and a real element made feasible the flotation of public debt denominated in domestic currency. There was a major overhaul of legislation concerning economic issues which affected themes as diverse as social security, job stability, funding for the housing sector, simplification of the foreign exchange regime, reduction of the anti-export bias and a less restrictive treatment of foreign direct investment. But on the whole one might say that there was a sustained emphasis on essential features that were present before 1964: a rather closed economy and massive state presence in the provision of goods and services.

There were new institutional arrangements involving insurance business in 1966 but there was no major break with the past. The main policy objective was still "to avoid the drain of foreign exchange”. The basic legal framework within which insurance activities take place in Brazil was established. ${ }^{59}$. The Decree-Law created the Private Insurance National System (SNSP) comprising the National Private Insurance Council (CNSP), the Brazilian Re-insurance Institute (IRB), the Private Insurance Superintendence (SUSEP) as well as the insurance companies and insurance brokers.

The CNSP's responsibilities included defining policies for private insurance and reinsurance as well as regulating the establishment, organisation, operation and supervision of entities undertaking activities within the SNSP. SUSEP was charged with implementing the policies defined by the CNSP, supervising firms operating within the SNSP, processing applications to operate or liquidate insurance companies and approving contracts coverage and premiums. The IRB's competence included acceptance of mandatory or optional re-insurance both in Brazil and abroad. Insurance companies had to re-insure with the Institute liabilities exceeding their retention limits. The IRB was also responsible for placing overseas insurance and re-insurance; re-insurance operations

${ }^{59}$ Decree-Law 73 of 1966. 
abroad were usually restricted to the excess the domestic market could not absorb, based on the technical retention capacity of the Institute and retrocession consortia administered by the IRB whose membership was compulsory for all insurance companies operating in Brazil

The total number of insurance firms remained roughly constant between the early 1960s and the early 1970s - around 190 - then fell sharply to less than 100 in the early 1980s. Of the 29 foreign insurance companies operating in 1979 only 3 remained in operation in the early 1980s. There was a monotonic fall in the share of business by foreign companies indirectly reflected in the fall of their share in total assets from $35.6 \%$ in 1939 to $16.7 \%$ in 1946 and $14 \%$ in 1963 . Foreign direct investment in insurance remained rather small: it was still below US\$ 90 million in the early 1980s.

The transfer of compulsory work accident insurance to the Ministry of Labour in 1967 makes unadjusted long-term comparisons of premium-GDP ratios somewhat misleading as the business corresponded to about $25 \%$ of total premiums in the early 1960s. The premium-GDP ratios (excluding work accident insurance) remained in the 0.9-1.0 range with GDP increasing 7.8\% yearly in 1964-1980. More recently the National Social Security Institute (INSS), hierarchically linked to the Ministry of Social Security, is the sole authorized supplier of worker's compensation insurance. ${ }^{60}$

Insurance business in the early 1980s was heavily concentrated in the Southeast - about $81 \%$ of total premiums - and less comprehensive more recent data suggest that this may have been reduced to about two thirds of the total in $2007 .{ }^{61}$

Compulsory auto accident insurance was introduced in 1966 with a significant impact on the composition of total premiums. Excluding work accident insurance from the total of

\footnotetext{
${ }^{60}$ WTO (2005), pp. 151-153.

${ }^{61}$ Anuário Estatístico do Brasil 1983, p.792 and http://www.fenaseg.org.br. The share of the Southeast in total GDP in 2007 was around 56\%, see: http://www.ibge.gov.br/home/estatistica/economia/contasregionais/2003_2007/tabela02.pdf
} 
premiums, between 1963 and 1970 the share of auto insurance more than doubled to $32.4 \%$ while fire insurance fell to $23.9 \%$ (from 32.\%) and life insurance remained around 18\%. If overall insurance business in Latin America is compared to that in East Asia a striking feature until 1990 was the much lower share of life business as compared to nonlife (typically hovering around 25\% of total business as compared to $75 \%$ ). ${ }^{62}$

The persistently negative insurance account in the balance of payments (outflow of around US\$ 10 million yearly from 1947 to the mid-1970s) lent strength to a major shift of policy in the IRB in the direction of seeking reinsurance business abroad. Amidst statements stressing the "impotence of liberal capitalism" there was a move towards an increase in the international reinsurance operations of IRB. ${ }^{63}$ An IRB office was opened in London and business in New York was conducted by the United Americas Insurance Co, ultimately controlled by IRB. A sharp rise in IRB revenues and a temporary reversal of outflows related to insurance (average net inflows US\$120 million yearly) followed, but the whole process would be reversed and lead to severe losses after the early 1980s.

There was also a sustained increase in IRB's share to around $40 \%$ of the total reinsurance business in the 1970s and 1980s (total premiums of US\$3.2 and 4.3 billion, respectively) as compared to less than $12 \%$ in the 1960 s (total premiums of US\$353 million). Domestically-placed retrocession fell from $70.4 \%$ to $40 \%$ of the total reinsurance while the share of those placed abroad remained around $16-17 \% .{ }^{64}$

\section{Economic stagnation and very high inflation: 1980-1993}

With the oil shock of 1979 and the rise in international interest rates there was an acceleration of inflation, after a succession of failed stabilisation plans, from $40 \%$ a year to more than $80 \%$ monthly in the early 1990s. This stimulated increasing doubts about the costs and benefits of insisting on an economic strategy based on high protection and a

62 “East Asia and Latin America-the Most Dynamic Insurance Market of the Nineties?”, Sigma, Swiss/Re 6/92.

${ }^{63}$ International Insurance Monitor, November 1977.

${ }^{64}$ See Leopoldi (1998), table 7, quoting Consultec/Fenaseg. 
dominant role of the state as had been the case since the 1930s. In this macroeconomic context, after a truly outstanding growth performance until the 1970s - in the same league as Japan and South Korea since 1900 - the Brazilian economy stagnated in the 1980s and then grew very slowly until the early 2000s.

Between 1980 and 1993, GDP average yearly growth fell to 1.6\% and yearly average inflation rose to $426 \%$ (GDP deflator, yearly peak nearly $2600 \%$ in 1990). Foreign direct investment in insurance increased slowly in 1980-1993 roughly doubling from US\$ 80 to US\$ 160 million while total FDI trebled in same period. This was in spite of the stimuli to the inflow of new foreign capital in the insurance sector after 1986 with new rules allowing foreign participation in the capital of insurance firms provided this was limited to half the total capital and one third of the voting capital..

The number of insurance firms between the early 1980s and the early 1990s remained roughly stable with the number of insurance firms with foreign participation (foreign share in equity above 50\%) increasing significantly. ${ }^{65}$ In 1990 international sources reported 105 companies. The 18 foreign companies answered for $13.8 \%$ of total premiums. ${ }^{66}$ But foreign direct investment registered in the Brazilian Central Bank in 1995 was still at US\$150 million (less than $0.45 \%$ of total FDI stock)

The premium-GDP ratio increased very slowly to reach $1.3 \%$ in the early 1990 s. In the early 1990s, when high inflation was nearing its end, more than $72 \%$ of insurance premiums were concentrated in four branches: auto (34.9\%), health (17.4\%) - which had become available in the Brazilian market in the mid-1970s - life (11.3\%) and fire (9.1\%).

Price indexation rules were crucial to determine profitability of insurance companies due to asymmetrical indexation of revenues and expenditures. Only in 1987 did SUSEP

65 Based on the assumption that IBGE data and Sigma data are comparable. The IBGE official series on the number of companies was discontinued in the 1980s.

66 “East Asia and Latin America-the Most Dynamic Insurance Market of the Nineties?”. Sigma, Economic Studies 6/92. 
succeed in making compulsory for insurance companies to use monetary correction to adjust claim payments.

In the insurance industry the period after the early 1980s was dominated by IRB's crisis. In spite of statements in the mid-1980s that gross IRB profits were sufficient to cover losses generated by the London office, pay dividends and capitalize the institution, no less than two thirds of income from assets in 1983-84 was being eaten up by negative operational results. The London office was put in run off and UAIC went out of business after severe losses. In the mid-1990s IRB was still making yearly provisions concerning losses in UAIC in New York (US\$24 million) as well as in the London office (US\$230 million).

In addition to these losses in London and New York IRB suffered massive losses in its business related to export credit insurance. In February 2000, amidst the aborted process of privatizing IRB, there was a settlement by the Federal government of almost US\$900 million owed by Seguro de Crédito à Exportação (SCE), operated by IRB, to Finex (Fundo de Financiamento à Exportação), an extinct fund operated by the Bank of Brazil. ${ }^{67}$ The positive net balance of payments inflow of the late 1970s was reversed: in 1980-1985 it averaged US\$42 million yearly, US\$77 million in the second half of the 1980s, decreasing to US\$52 million in 1992-1993.

Under the 1988 Constitution, foreign access to Brazil's insurance market was relatively restricted. The incorporation of new branches and subsidiaries of foreign insurance companies, as well as increases in the percentage of the participation of foreign persons and firms in the capital stock of Brazilian insurance institutions with headquarters in

67 There were other losses as the US\$ 98 million deposited in the bankrupt Banco Econômico branch in the Cayman Islands. In 1997 the Brazilian government established an export credit guarantee fund and put in place an export credit insurance system on an entirely new basis. An Export Credit Insurance scheme overhauled the export insurance business which remains rather small: the Brazilian Export Credit Insurance Co. is the most important specialized institution operating with short-, medium and long-term transactions 
Brazil was not permitted. Imports could only be insured with companies established in Brazil; exports had to be insured in Brazil when the sale included the insurance cost. Regulation of the financial system was to be defined by constitutional amendments. ${ }^{68}$ After 1990 there were signs of mild flexibilisation of regulations as, for instance, those on SUSEP guidelines for setting premium rates.

\section{Since 1993: stabilisation, stalled reform and fast expansion of insurance business}

From the early 1990s the model of autarchy and heavy state intervention started to be comprehensively revised and there was a significant reduction of protection, considerable deregulation and privatisation of many state-owned concerns starting with industrial firms and then affecting providers of public services such as telecoms and electricity. In 1993-1994 chronic inflation was finally tamed with the implementation of the Real Plan. Privatisation of the financial sector proceeded at a much slower pace and the planned privatisation of IRB stalled after complex judicial wrangles. Much of the privatisation of the financial sector proceeded on an ad hoc basis and liberalisation was not bound in the World Trade Organisation pending parliamentary approval of new legislation. Late privatisation was also affected by changed circumstances related to the balance of payments crisis that hit the Brazilian economy in late $1998 .{ }^{69}$

There were 122 companies in Brazilian insurance market in 1995. 70 per cent of the market corresponded to insurers linked to financial institutions. Market concentration was high with the ten largest insurance firms collecting about 64 per cent of all premiums. ${ }^{70}$ High inflation and defective indexation were important deterrents of the expansion of premium-GDP ratios especially in the case of life insurance business. Following the success of stabilisation in 1994, the premium-GDP ratio doubled after hovering for a long period slightly above 1\%: it reached 2.15\% in 1998. It was a ratio higher than Mexico's, similar to that of Argentina, but lower than Chile's 3.39\% -- where a significant portion

${ }^{68}$ WTO (1997), pp. 157-163.

${ }^{69}$ See www. wto.org, GATS/SC/13/Suppl.3. Levy and Pereira (2007) is a good source on developments of the insurance business in the 1990s and early 2000s.

${ }^{70}$ WTO (1997), pp. 157-163. 
of the pension system was privatized -- and much lower than the more than $10 \%$ of South Korea. ${ }^{71}$ Non-life business answered for $60 \%$ of total business still in contrast to both Chile's and South Korea's share of about a third of the total.

After 1996 significant mergers and acquisitions took place as foreign insurance companies entered the Brazilian market. The share of foreign companies in premiums trebled to reach $17.9 \%$ in 1997 and then doubled to 35.1\% in 2002 but foreign direct investment in the insurance business remained around $0.5 \%$ of the total stock according to the 2000 census. $^{72}$

Brazil's list of commitments under the General Agreement on Trade in Services which resulted from the Uruguay Round included engagements concerning the participation of foreign capital in insurance, re-insurance and brokerage activities pending on the approval of legislation by Congress which has proved to be extremely slow. ${ }^{73}$

Procurement of insurance by the three levels of governments used to take place at set prices, with contracts allocated to insurers through a "lottery". Since 1993, the public sector has contracted insurance services through tenders opened to all insurers operating in Brazil. Prohibition on the entry of foreign capital in health insurance was lifted in 1996. $^{74}$

Legislation introduced in 1996 ended IRB's reinsurance monopoly. ${ }^{75}$ In 1997 IRB was included in the privatisation program, an official valuation was undertaken to establish a minimum price and legal adjustments were made to prepare its auction. IRB was renamed IRB Re and IRB's indebtedness with FINEX, as already mentioned, of no less than US\$893 million was transferred to the Federal government prior to planned privatisation.

71 The other striking feature of the South Korean insurance industry was the low participation of foreign firms, Sigma 4/2000.

${ }^{72}$ Data supplied by the Brazilian Central Bank. There are discrepancies between stock data bases

${ }^{73}$ WTO (1997), pp. 157-163.

${ }^{74}$ Law 8666. WTO (1997), pp. 157-163

${ }^{75}$ Constitutional Amendment 13 of August 1996. 
This was controversial as it was deemed to unduly favor private insurers that held a minority IRB Re's stake. ${ }^{76}$

There were two attempts to privatize IRB Re but doubts on valuation methods marked the whole process. In the end it was the transfer in 1999 to SUSEP of supervision of reinsurance and retrocession operations previously undertaken by IRB that caused major problems and aborted the process. Up to 1999, SUSEP was responsible for the control and supervision of insurance, open private pension funds - which had been created by new legislation in $1997^{77}$-- and capitalisation operations, while IRB supervised the reinsurance and retrocession operations. The then main opposition party - which would win the presidential elections in 2002 and again in 2006 - successfully argued in the Supreme Court that this was unconstitutional. A decision on the matter was postponed sine die. ${ }^{78}$

The 2002 presidential elections subjected Brazilian economic policy to a stiff credibility test. As the date of the elections approached uncertainty concerning future macroeconomic policy led to sharp devaluation of domestic currency. ${ }^{79}$ The economic program of the main party in the coalition supporting the leading candidate was rather radical firmly rooted in old fashioned nationalism and state intervention. The proposals to default public debt are perhaps emblematic of its nature. To avoid such tensions all candidates subscribed an agreement that there would be no sharp reversal of prudent macroeconomic policies whatever the result. To the surprise of many observers the fiscal and monetary policies adopted under President Lula's government to a large extent consolidated stabilisation achieved under President Cardoso.

In December 2003, there were 130 insurance companies (of which 14 were health insurance companies), 15 investment plan companies, and 29 open private pension fund

\footnotetext{
${ }^{76}$ Provisional Measure, 10.4.2000. This was about four times IRB's valuation.

${ }^{77}$ Law 9477, 24.7.1997.

${ }^{78}$ Law 9932, 20.12.1999. WTO (2000), pp. 107-108.

${ }^{79}$ The exchange rate approached a peak of almost 4 Reais/US\$ in 2002 compared to2.4 Reais/US\$ in beginning of the year and 1.7 Real/US\$ towards the end of 2009.
} 
societies in operation. These numbers remained stable until mid-2008. ${ }^{80}$ The premiumGDP ratio rose to $2.99 \%$ with almost equivalent shares of life and non-life business. ${ }^{81}$ This was not far from Chile's 3.54\% even if in Brazil there had been no overhaul in the public pension scheme. $^{82}$

New legislation passed in 2007 provided a new framework for re-insurance business in Brazil, as it opened the reinsurance sector to foreign-owned and foreign-based companies. The operations of reinsurance and retrocession can now be held with the local reinsurer (established as a corporation, with the sole object of conducting operations of reinsurance and retrocession), with the admitted re-insurer (based abroad, with office of representation in Brazil, registered with SUSEP to carry out operations of reinsurance and retrocession); and with the foreign re-insurer (foreign reinsurance company based abroad without office of representation in Brazil also registered as such in SUSEP). The law allows Brazilian legal persons to take out insurance abroad to cover risks abroad, provided this is notified to the SUSEP. Prior to it cross-border supply of insurance services was not allowed, unless in very special circumstances. The situation of the Brazilian reinsurance market changed substantially as IRB-Brasil Re (successor of IRB) ceased to be the sole provider of re-insurance. Towards the end of 2008 there were 21 reinsurance companies operating: three local, ten as admitted and eight as occasional. ${ }^{83}$

In the industry as a whole there was a further modest increase in the participation of foreign capital in the insurance industry's premium income which rose $36.9 \%$ in 2007 . In the open private pension funds, foreign capital participation grew from 21\% in 1999 to 30.7\% in 2007. Between 2000 and 2001 foreign direct investment in insurance more than doubled to reach US\$ 1120 million, then doubled again to reach US\$ 2472 million by the

\footnotetext{
${ }^{80}$ WTO (2005) and WTO (2009).

${ }^{81} 59.6 \%$ for life and health insurance, $25.3 \%$ for motor vehicle insurance, and the rest for fire, transportation, and other risks, WTO (2009).

82 "World insurance in 2007: emerging markets leading the way" Statistical appendix updated December 2008, Sigma 3/2008.

${ }^{83}$ WTO (2009).
} 
end of 2008 (more than $0.9 \%$ of total stock). ${ }^{84}$ In parallel with the increasing importance of insurance in FDI the insurance account in the balance of payments became significantly negative: US\$ 336 million on average in 2000-2004, US\$ 520 million in 2005-2008.

The Brazilian national insurance system after the introduction of partial reforms in the 1990s and 2000s is now composed of the National Council of Private Insurance (CNSP), the Superintendence of Private Insurance (SUSEP) and the reinsurers, besides private insurance companies and authorized brokers. The CNSP is the main body responsible for setting policies for the private insurance industry, including the definition of the characteristics of different insurance contracts, and for the regulation of the national insurance system. SUSEP, an autonomous body under the organisational structure of the Ministry of Finance, has responsibility for the control and supervision of insurance, reinsurance, open private pension funds, and capitalisation (investment plans) operations. SUSEP is the industry regulator, executes the CNSP policies and has recently introduced new mechanisms of risk management into the insurance, open private pension funds and capitalisation markets moving towards a risk-based supervisory regime consistent with international standards and practices, such as the International Association of Insurance Supervisors. Furthermore, SUSEP is encouraging the creation and development of popular insurance products. Supervision of the health insurance business is the responsibility of the National Health Agency (ANS), under the organisational chart of the Ministry of Health. ${ }^{85}$

The insurance industry in Brazil was quite concentrated in 2008: in life insurance and private pension funds the top 10 companies answered for $81 \%$ of total retained premiums sold by the 50 largest companies. Companies controlled by banks (Bradesco Vida $e$ Previdência, Aliança do Brasil, Santander Seguros, HSBC Seguros and Itaú Vida) sold

${ }^{84}$ See www.bcb.gov.org. Stock estimates result from the accumulation of flow data taking the 2000 and 2005 census estimates as initial stocks. Central Bank data may underestimate as the line corresponding to "ancillary activities related to financial intermediation" includes some investment in insurance.

${ }^{85}$ WTO (2009). 
more than $50 \%$ of this total. Aliança do Brasil is controlled by Banco do Brasil, a commercial bank controlled by the Federal government. Other companies in the top 10 included three independent Brazilian insurance companies (Unimed Seguros, Icatu Hartford $^{86}$, Sul América Vida e Previdência) as well as two foreign companies (Mapfre Vera Cruz Vida e Previdencia and Metlife Seguros e Previdência).

Non-life business was similarly concentrated with the market share of issued premiums of $81.6 \%$ of the top 10 companies in the premiums issued by the top 50 . Companies controlled by banks (Bradesco Seguros, Porto Seguro, Unibanco Seguros e Previdência, Itaú Seguros e Caixa Seguros) sold almost 50\% of this total. Caixa Seguros is controlled by Caixa Econômica Federal, a commercial bank controlled by the Federal government. Other companies in the top 10 included one independent Brazilian insurance company (Sul América) as well as four foreign companies (Mapfre Vera Cruz Seguradora, Allianz Seguros, Liberty Mutual and Tokio Marine). ${ }^{87}$

Due to the prudent fiscal and monetary policies adopted -- especially after 1998 -- the Brazilian economy, although hardly hit by the sharp fall in commodity export prices has proved to be resilient in face of the world economic crisis. The financial sector, strengthened by policies to face former crises in the late 1990s, proved to be extremely solid, even if compared to those in the developed economies. The results of sound macroeconomic policy, important new oil findings and an early recovery of economic activity have been attracting a significant inflow of foreign capital. Sustained high rates of growth seem achievable after many years of slow growth.

To a large extent the expansion of the insurance industry in Brazil after the mid-1990s has been the result of the combination of macroeconomic and microeconomic favourable factors. After a long experience of unbalanced public finance and very high inflation sustained stabilisation was achieved. There was a partial overhaul of the regulatory

\footnotetext{
${ }^{86}$ Hartford's participation has been acquired recently by their Brazilian partners.

${ }^{87}$ Valor 1000, edição 2009, agosto 2009, ano 9, número 9.
} 
framework relevant for the insurance industry and a significant opening of the market to foreign competition.

Two new developments are likely to have a significant impact on insurance business in the longer term. There have been major offshore oil discoveries in Brazil, especially since 2008, which are likely to transform the country -- which is now self sufficient -- into a major oil exporter towards the end of the 2010s. The other favourable development is the impact of redistributive policies and improved recent growth performance on income distribution. The market for "popular insurance" has increased using the network of commercial banks, credit card companies and billing of companies providing public services. Legislation on "micro insurance" targeting low income groups and with an element of subsidy is being considered by Congress.

In a very long-term perspective, the insurance business in Brazil may be seen as marked by a strong shift towards more state intervention combined with regulation designed to crowd foreign firms out of the Brazilian market. This peaked in the late 1970s and was followed by a rather slow liberalisation with a reduction in regulation with a nationalistic bias and an increased market share of foreign firms.

After an extremely low take off in the $19^{\text {th }}$ century, insurance business grew in importance in the virtual absence of regulation. But as a result of the major balance of payments in 1890s, following the transition to a republican regime, there was an early move towards much more control of the activities of foreign firms and the proposal of legislation that would effectively discriminate against them. These initiatives under minister Murtinho - who is generally credited with the implementation of orthodox economic policies - were strongly criticized and not wholly implemented.

But the balance of payments difficulties related to the great 1929-1932 recession created conditions for the introduction -- or reintroduction -- of legislation with a bias in favour 
of direct government involvement in the business, much tighter regulation and effective discrimination of foreign firms in favour of domestic or government-controlled institutions. The Instituto de Resseguros do Brasil was emblematic of such shift in policy that was akin to import substitution in manufacturing industry. The nationalistic trend culminated in the 1970s in the attempt to enhance the international role of IRB which ended in utter failure.

Since then, liberalisation has been slowly progressing. In spite of the aborted privatisation of IRB in 2000, a combination of an extensive regulatory overhaul, the expansion of new branches in the industry - such as private pension funds - and the end of high inflation, opened new opportunities for a significant expansion of the insurance business combined with an increased share of foreign companies. Dominant insurance companies, however, continued to be controlled by the big Brazilian commercial banks.

Although the insurance industry in Brazil still faces significant problems related to low efficiency and barriers to competition in an environment which is less favourable to liberalisation than before 2003, its prospects have never been so good in a context of low inflation and high prospective growth.

\section{References}

Abreu, M. de P., “The Brazilian economy, 1930-1980”, in Leslie Bethell (ed.) The Cambridge History of Latin America, v. 9, Cambridge: Cambridge University Press, 2008.a

Abreu, M. de P. “The Brazilian economy, 1980-1994”, in Leslie Bethell (ed.), The Cambridge History of Latin America, v. 9, Cambridge: Cambridge University Press, 2008.b

Abreu, M. de P. and L.A.C. do Lago, "Property rights and the fiscal and financial systems in Brazil”, in Michael Bordo and Roberto Cortés-Conde (eds.), Transferring Wealth and Power from the Old to the New World, Cambridge: Cambridge University Press, 2001. 
Abreu, M. de P. and Rogério L.F. Werneck, "The Brazilian economy from Cardoso to Lula, 1995-2004: an interim view", in Leslie Bethell (ed.), The Cambridge History of Latin America, v. 9, Cambridge: Cambridge University Press.

Alberti, V. (ed.), M.A.P. Leopoldi, M.S.da Motta, C.E. Sarmento and R.C.R. da Costa, Entre a solidariedade e o risco: história do seguro privado no Brasil, Rio de Janeiro: Funenseg and FGV, 1998.

Banco Central do Brasil, Anexo Especial II, Investimento e reinvestimento de capitais estrangeiros, 1974

Banco Central do Brasil, Boletim Especial, vol. 24 no. 1, January 1988

Banco Central do Brasil, www.bcb.gov.org

Brasil, Código Commercial de 1850

Brasil. Sociedades Mercantis autorizadas a funcionar no Brasil: 1808-1946, Rio de Janeiro: Dep. Nac. de Indústria e Comércio, 1947.

Brasil. Bahia. Falla com que o Exm. Sr. Commendador Antonio Candido da Cruz Machado abriu a $1^{\text {a }}$ Sessão da Vigésima Legislatura da Assembléia Legislativa Provincial da Bahia no dia $1^{\circ}$ de Março de 1874, Salvador ( http://brazil.crl.edu/bsd/bsd/146).

Brasil. Ministério da Fazenda. Ministro José Maria da Silva Paranhos, Proposta e Relatório do Anno de 1860 Apresentados à Assembléia Geral Legislativa na $1^{\text {a }}$ Sessão da 11ª Legislatura (inclui Annexos) 1861 (http://brazil.crl.edu/bsd/bsd/u1541).

Brasil. Ministério da Fazenda. Ministro José Maria da Silva Paranhos, Proposta e Relatório do Anno de 1872 Apresentados à Assembléia Geral Legislativa na $2^{\text {a }}$ Sessão da 15ª Legislatura (inclui Annexo) 1873 (http://brazil.crl.edu/bsd/bsd/u1554).

Brasil. Ministério da Fazenda. Ministro Joaquim Murtinho. Relatório do Ano de 1901 Apresentado ao Presidente da República dos Estados Unidos do Brasil no ano de 1902. Inclui Anexo (http://brazil.crl.edu/bsd/bsd/u1756).

Brasil. Ministério da Fazenda. Ministro Leopoldo de Bulhões. Relatório do Ano 1902 Apresentado ao Presidente da República dos Estados Unidos do Brasil em 1903. Inclui Anexos (http://brazil.crl.edu/bsd/bsd/u1757/000001.html).

Brasil. Ministério da Fazenda. Ministro Leopoldo de Bulhões. Relatório do Ano de 1909 Apresentado ao Presidente da República dos Estados Unidos do Brasil no Ano de 1910. Inclui Anexo (http://brazil.crl.edu/bsd/bsd/u1761/000001.html).

Brasil. Ministério da Fazenda. Relatório Apresentado ao Vice-Presidente da República dos Estados Unidos do Brasil em exercício pelo ministro dos negócios da Fazenda, João 
Ribeiro de Oliveira e Souza no Anno de 1919 (http://brazil.crl.edu/bsd/bsd/u1770/000001.html).

Brasil. Ministério da Fazenda. Relatório Apresentado ao Presidente da República dos Estados Unidos do Brasil pelo ministro dos negócios da Fazenda R. A. Sampaio Vidal no ano de 1923 (http://brazil.crl.edu/bsd/bsd/u1772/000001.html).

Brasil. Ministerio da Fazenda. Ministro Anibal Freire da Fonseca. Relatório do Ano de 1925 Apresentado ao Presidente da República dos Estados Unidos do Brasil no Anno de 1926 (http://brazil.crl.edu/bsd/bsd/u1773/000001.html).

Chaufton, A., Les assurances: leur passé, leur présent, leur avenir au point de vue rationnel, technique et pratique, moral, économique et social, financier et administratif, légal, législatif et contractuel en France et à l'étranger, Paris: Librairie A. Marescq Ainé, 1884.

Contador, C. (ed.), Desafios e oportunidades no mercado de seguros: uma coletânea de estudos, Rio de Janeiro: Centro de Estudos e Pesquisas em Seguros, COPPE/UFRJ, 1999.

Daudt, N., “O Instituto de Resseguros do Brasil e o Mercado Brasileiro de Resseguros”, monografia, Department of Economics, PUC-Rio, June , 2001.

Dean, W., Rio Claro: a Brazilian plantation system, 1820-1920. Stanford, Calif.: Stanford University Press, 1976.

Departamento Nacional do Café, O Café no $2^{\circ}$ Centenário de sua Introdução no Brasil. Rio de Janeiro, Departamento Nacional do Café, 1934.

Falcão, W., O Ministério do Trabalho no Estado Novo. Relatório das atividades dos departamentos, serviços e institutos nos anos de 1938, 1939 e 1940, Rio de Janeiro: Imprensa Nacional, 1941

Fenaseg-Federação Nacional das Empresas de Seguros Privados e de Capitalização, www.fenaseg.org.br.

Franco, G. H. B., A Primeira Década Republicana. In: Abreu, M. de P. (ed.). A Ordem do Progresso: Cem Anos de Política Econômica Republicana, 1889-1989. Rio de Janeiro: Campus, 1990.

Fritsch, W., External Constraints on Economic Policy in Brazil, 1889-1930, Basingstoke, Hants: Macmillan, 1988

[Fundação] Instituto Brasileiro de Geografia e Estatística, Anuário Estatístico, Rio de Janeiro, several issues. 
[Fundação] Instituto Brasileiro de Geografia e Estatística, http://www. ibge.gov. br/ home /estatistica/economia/contasregionais/2003_2007/tabela02.pdf (regional GDP).

International Insurance Monitor, November 1977.

Graham, Richard. Britain \& the Onset of Modernization in Brazil, 1850-1914, Cambridge Latin American Studies, Cambridge University Press, 1972.

Instituto de Resseguros do Brasil, Coletânea da Legislação Brasileira de Seguros, 18281941. Rio de Janeiro: IRB, Publicação n. 9, 1942.

IPEA, www.ipeadata.gov.br

IRB-Brasil Resseguros, www2.irb-brasilre.com.br/site

Leopoldi, M.A.P., "Os anos de incerteza:redemocratização, globalização financeira e desregulação do setor de seguros privados (1985-98)” in Alberti et al (1998).

Levy, A. and F. C. Pereira, "Recent developments in the Brazilian insurance market" in Cummins, J. David; Venard, Bertram (eds): Handbook of International Insurance. Between Global Dynamics and Local Contingencies, New York: Springer, 2007.

Post Magazine and Insurance Monitor 17 January 1889.

Póvoas, M. S., Na rota das instituições de bem-estar: seguro e previdência. São Paulo: Academia Nacional de Seguros e Previdência, São Paulo, Editora Green Forest do Brasil, 2000.

Saes, A. M. and T. F. R. Gambi, "Securing capital: the formation of insurance firms in Brazil (1808-1864)", paper presented at the XVth World Economic History Congress, Helsinki, 2009.

Sigma, Zurich, several issues.

Villela, A. A.. "The Political Economy of Money and Banking in Imperial Brazil, 18501870”, London, London School of Economics, PhD Thesis, 1999.

Superintendência de Seguros Privados, www.susep.gov.br

Valor 1000, edição 2009, agosto 2009, ano 9, número 9.

World Trade Organisation , Trade Policy Review Brazil 1996, Geneva, March 1997.

World Trade Organisation , Trade Policy Review Brazil 2000, Geneva, December 2000. 
World Trade Organisation, Trade Policy Review Brazil 2004, Geneva, February 2005.

World Trade Organisation, Trade Policy Review Brazil 2009, Geneva, June 2009.

World Trade Organisation, www. wto.org, GATS/SC/13/Suppl.3. 